Please note that this PDF file replaces the first version of the manuscript e076 in which density $\left(\mathrm{kg} / \mathrm{m}^{3}\right)$ appeared with incorrect units. 


\title{
Study of potential advantages of pre-soaking on the properties of pre-cast concrete made with recycled coarse aggregate
}

\author{
Z. Sánchez-Roldán ${ }^{\mathrm{a}}$, M. Martín-Morales ${ }^{\mathrm{a}} \bowtie$, I. Valverde-Palacios ${ }^{\mathrm{a}}$, I. Valverde-Espinosa $^{\mathrm{a}}$, M. Zamorano ${ }^{\mathrm{b}}$ \\ a. ETS de Ingeniería de Edificación, University of Granada (Granada, Spain) \\ b. ETS Ingenieros de Caminos, Canales y Puertos, University of Granada (Granada, Spain) \\ $\triangle$ mariam@ugr.es
}

\author{
Received 24 February 2015 \\ Accepted 10 July 2015 \\ Available on line 15 january 2016
}

\begin{abstract}
Recycled aggregate (RA) from construction and demolition waste is traditionally used for the manufacture of concrete for different applications. Due primarily to high water content required by RA, the quality of the concrete is determined by the amount of replacement RA. The aim of this study is to determine if RA pre-soaking enhances the properties of pre-cast concrete for street furniture, with low mechanical and structural requirements, in which $100 \%$ of the coarse fraction is replaced. The results of physical and mechanical tests performed on concrete specimens in which the RA was pre-soaked using five different methods applied are compared with a reference concrete sample and a concrete sample made with non-pre-soaked RA. The results show that non-pre-soaked RA offers improved physical-mechanical properties for pre-cast concrete, except for the workability; problems arising from poorer workability could be improved with the use of plasticizers, which can be easily included in the production process.
\end{abstract}

KEYWORDS: Concrete; Aggregate; Pre-cast; Waste treatment; Workability

Citation/Citar como: Sánchez-Roldán, Z.; Martín-Morales, M.; Valverde-Palacios, I.; Valverde-Espinosa, I.; Zamorano, M. (2016) Study of potential advantages of pre-soaking on the properties of pre-cast concrete made with recycled coarse aggregate. Mater. Construcc. 66 [321], e076. http://dx.doi.org/10.3989/mc.2016.01715.

RESUMEN: Estudio de las ventajas potenciales del premojado en las propiedades del hormigón prefabricado con árido reciclado grueso. El árido reciclado (AR) procedente de residuos de construcción y demolición se utiliza tradicionalmente en la elaboración de hormigón para diferentes aplicaciones. Debido principalmente al mayor contenido en agua requerido por el AR, la calidad del hormigón está determinada por la cantidad de AR reemplazado. El objetivo de este estudio es determinar si el AR premojado mejora las propiedades del hormigón prefabricado para mobiliario urbano, con bajas exigencias mecánicas y estructurales, en el que se sustituye el 100\% de la fracción gruesa. Los resultados de los ensayos físicos y mecánicos realizados sobre muestras de hormigón en las cuales el AR se ha premojado usando cinco métodos diferentes se han comparado con una muestra de hormigón de referencia y una muestra de hormigón fabricada con AR no premojado. Los resultados muestran que el AR no premojado proporciona propiedades físico-mecánicas mejoradas en el hormigón prefabricado, a excepción de la trabajabilidad; los problemas derivados de una deficiente trabajabilidad pueden ser fácilmente corregidos con la incorporación de plastificantes en el proceso de fabricación.

PALABRAS CLAVE: Hormigón; Árido; Prefabricado; Tratamiento de residuos; Trabajabilidad

Copyright: (C) 2016 CSIC. This is an open-access article distributed under the terms of the Creative Commons Attribution-Non Commercial (by-nc) Spain 3.0 License. 


\section{INTRODUCTION}

The construction industry has several negative effects on the environment, including the consumption of raw materials and the generation of construction and demolition waste (C\&DW). These activities contribute significantly to environmental degradation at different stages: extraction and manufacture of materials, design, construction and M\&E services (Maintenance and Evaluation services). The construction industry is a major generator of largevolume waste with an important visual impact. The composition of this waste is mainly inert, although some C\&DW is hazardous (1). However, C\&DW can be treated in appropriate industrial facilities to produce recycled aggregate (RA) that can be used to replace natural aggregate (NA) (2). For example, road construction (3), masonry mortar $(4,5)$, structural and non-structural concrete $(6,7)$, and even in pre-cast concrete products such as paving blocks (8), paving flags (9), kerbs (10) or partition wall blocks (11).

RA from concrete differs from NA in that it often contains impurities such as crushed clay brick, crushed ceramic material and gypsum as well as mortar adhered to the original NA $(7,12,13)$. These impurities introduce several contaminants into the aggregate, such as chlorides, sulphates and other harmful materials. Consequently, the use of RA in the manufacture of concrete can affect the workability, mechanical performance and durability of the finished product (13-17).

The higher water absorption capacity of RA is the result of the presence of mortar adhered to the original aggregate $(7,12,13,18)$. This feature of RA may cause mixing problems due to poorer workability, resulting in a lower water/cement (w/c) ratio in the paste and less compressive strength. Therefore, special precautions must be taken during the mixing process (6). In view of this, many studies have compared concrete containing RA with different levels of humidity $(12,19,20)$ and developed dosage methods that have had a major effect on the properties of fresh and hardened concrete. In these studies, saturated RA was not recommended because it could cause bleeding problems that may have a detrimental effect on the strength of hardened concrete, resulting in the failure of an effective interfacial transition zone between the saturated recycled coarse aggregates and the new cement paste $(12,21,22)$. Nevertheless, some authors recommend setting the humidity level at $80 \%$ of the total absorption capacity of the RA to ensure the presence of water on the aggregate surface. This guarantees the attachment of a large quantity of cement particles and improves the bond between the cement paste and aggregate $(14,22,23)$; however, other humidity percentages have been also reported $(13,24)$.
The characteristics of RA, particularly its high water absorption, limit the use of this material in the manufacture of concrete. Studies such as that of Etxeberria et al. (14) and Kou (25) focus on the properties of recycled concrete (RC) for use as structural concrete, and report satisfactory results provided that less than $25 \%$ of the coarse fraction is replaced. Other studies have demonstrated the feasibility of using RA in the production of nonstructural concrete $(13,15,26)$ such as concrete blocks for use in partition walls $(11,27)$, paving blocks $(8-10,28-30)$, paving flags $(8,31)$ and concrete kerbs and floor blocks (10). These studies have shown that the quality of the pre-cast elements depends on the extent to which NA is replaced by RA, with values that ranged from $25-50 \%$ for paving blocks, $30-65 \%$ in the case of paving flags, $50 \%$ for kerbs and partition wall concrete blocks, or even $100 \%$ in the manufacture of floor blocks. This mainly refers to the mechanical behaviour of precast elements, which is not compromised, and does not address the chemical and physical impact this granular material may have on this kind of pre-cast element.

It is not found references to the use of RA as aggregate in the manufacture of non-structural concrete for street furniture such as concrete benches, fountains, planters, beach walkways, etc. This type of pre-cast concrete has lower mechanical and structural requirements, according to EN 13198 (32), and in this case replacing $100 \%$ of the coarse fraction with RA could be an advantage. However, the concrete must be sufficiently workable to facilitate the use of moulds, and in this respect the higher water absorption of RA may be a limiting factor. In this case workability can be improved by the use of plasticizers or by increasing the amount of mixing water, thereby reducing mechanical strength (33).

Pre-soaked RA could improve the behaviour of recycled concrete by preventing the transfer of water between the RA and the cement paste. This would reduce the amount of water required to achieve greater strength and lower water absorption. This study, therefore, focuses mainly on determining the benefits of pre-soaked recycled coarse aggregate (RCA) on the properties of fresh and hardened concrete after replacing natural coarse aggregate (NCA) with RCA. Five pre-soaking methods have been formulated, which differing mainly in terms of pre-soaking time, the amount of water added to the mix, and the mixing time, and then tested and compared these against an RC containing non-pre-soaked RCA and a concrete with NCA. The methods were analysed to determine the potential advantages of pre-soaking on the properties for pre-cast concrete for beach walkways made with RCA. 


\section{MATERIALS AND METHODS}

\subsection{Materials}

Concrete is composed of sand and coarse aggregate, cement and additives. In this study, two types of concrete were manufactured using NA and RA, respectively. The components used to manufacture both types of concrete are described below:

- Cement. The cement used in this study was BL I 42.5R.

- Additive. The water-reducing admixture (Chryso ${ }^{\circledR}$ fluid Optima 227) was used to improve the workability of concrete.

- Aggregate. NA and RCA were used in this study. Their physical, mechanical and chemical properties and the standards applied are summarized in Table 1 (35-39). NAs were produced in a local quarry in Granada, Spain, and the RCA was produced in a C\&DW treatment and recovery plant located in Alhendín in the Spanish province of Granada. The RCA was obtained from RA from civil engineering concrete waste which, according to EN 933-11 (39), included: $88.8 \%$ crushed concrete, $9.1 \%$ aggregate natural, $0.2 \%$ ceramic aggregate, $1.8 \%$ bituminous and $0.1 \%$ other impurities. This particular RCA was classified as recycled concrete aggregate (40), and under EHE-08 (34) guidelines (Table 1) was determined to be of good quality due to an acceptable level of impurities, except for $1.8 \%$ of asphalt. The particle size distribution of both aggregates, shown in Figure 1, was continuous, ensuring that the aggregate would have a positive effect on the workability of the concrete (41). With regard to fines content, RCA had not a high proportion of fine particles. Due to their characteristics, both aggregates were shown to be suitable for concrete (42), although as expected the saturated-surface-dry particle density of RCA was lower and water absorption higher than NA, this is due to old mortar that adheres to RCA (16).

\subsection{Methods}

\subsubsection{Pre-soaking method}

Five pre-soaking methods were tested, 4 of them (Method 1 to 4) from the literature $(7,13,14,24)$ and a fifth proposed by us (Method 5). Pre-soaking methods varied in terms of total water, procedure for adding pre-soaking water, pre-soaking time, and mixing time. Figure 2 shows the characteristics of all the methods used in the study, and the corresponding concrete series produced.

\subsubsection{Concrete samples}

For the purpose of the study, a control series (Series C) using NA and 6 further series in which RCA totally replaced NCA (methods 0 to 5) were manufactured according to the manufacturer's recommended dosage and the concrete quality control data (Table 2) for the manufacture of articulated concrete slabs for beach walkways. Figure 2 shows the respective mixture components and the order in which they should be added, as well as the presoaking and mixing times required for each method. Table 3 summarizes the data related to the water content, wherein the w/c effective ratio of 0.48 is constant for all methods.

TABLE 1. Aggregate properties according to EHE-08 (34)

\begin{tabular}{|c|c|c|c|c|c|c|}
\hline \multirow[b]{2}{*}{ Property } & & \multirow[b]{2}{*}{ Standard } & \multicolumn{2}{|c|}{ NA } & \multirow{2}{*}{$\begin{array}{c}\text { RA } \\
\text { RCA } \\
\end{array}$} & \multirow{2}{*}{$\begin{array}{l}\text { Limit } \\
\text { value }\end{array}$} \\
\hline & & & NFA & NCA & & \\
\hline - Fraction (d/D) & & EN 933-1 (35) & $0 / 4$ & $4 / 16$ & $4 / 16$ & - \\
\hline - Sieve distribution & & EN 933-1, $2(35,36)$ & Continuous & Continuous & Continuous & - \\
\hline \multirow{2}{*}{$\begin{array}{l}\text { - Material fines than } \\
\quad<0.063 \mathrm{~mm} \mathrm{( \% )}\end{array}$} & Fine aggregate & EN 933-1 (35) & 0.50 & - & - & $6-16$ \\
\hline & Coarse aggregate & & - & 0.90 & 0.30 & 1.5 \\
\hline \multicolumn{2}{|c|}{ - Saturated-surface-dry particle density $\left(\mathrm{kg} / \mathrm{m}^{3}\right)$} & EN 1097-6 (37) & 2635 & 2733 & 2595 & - \\
\hline \multirow[t]{2}{*}{ - Water absorption (\%) } & $24 \mathrm{~h}\left(W A_{24 h}\right)$ & EN 1097-6 (37) & 1.02 & 0.379 & 2.136 & $\leq 5$ \\
\hline & $10 \mathrm{~min}$ & & - & - & 1.935 & - \\
\hline - Moisture content $(\%)$ & & EN 1097-5 (38) & 0.43 & - & 0.30 & - \\
\hline \multirow[t]{3}{*}{ - RCA composition (\%) } & $\begin{array}{l}\text { Constituent metal, glass, soft } \\
\text { materials, bitumen }\end{array}$ & EN 933-11 (39) & - & - & 0.1 & $<1$ \\
\hline & Constituent asphalt & & - & - & 1.8 & $<1$ \\
\hline & Constituent ceramic material & & - & - & 0.2 & $<5$ \\
\hline
\end{tabular}

(-) Test not performed or no restrictions for this parameter 


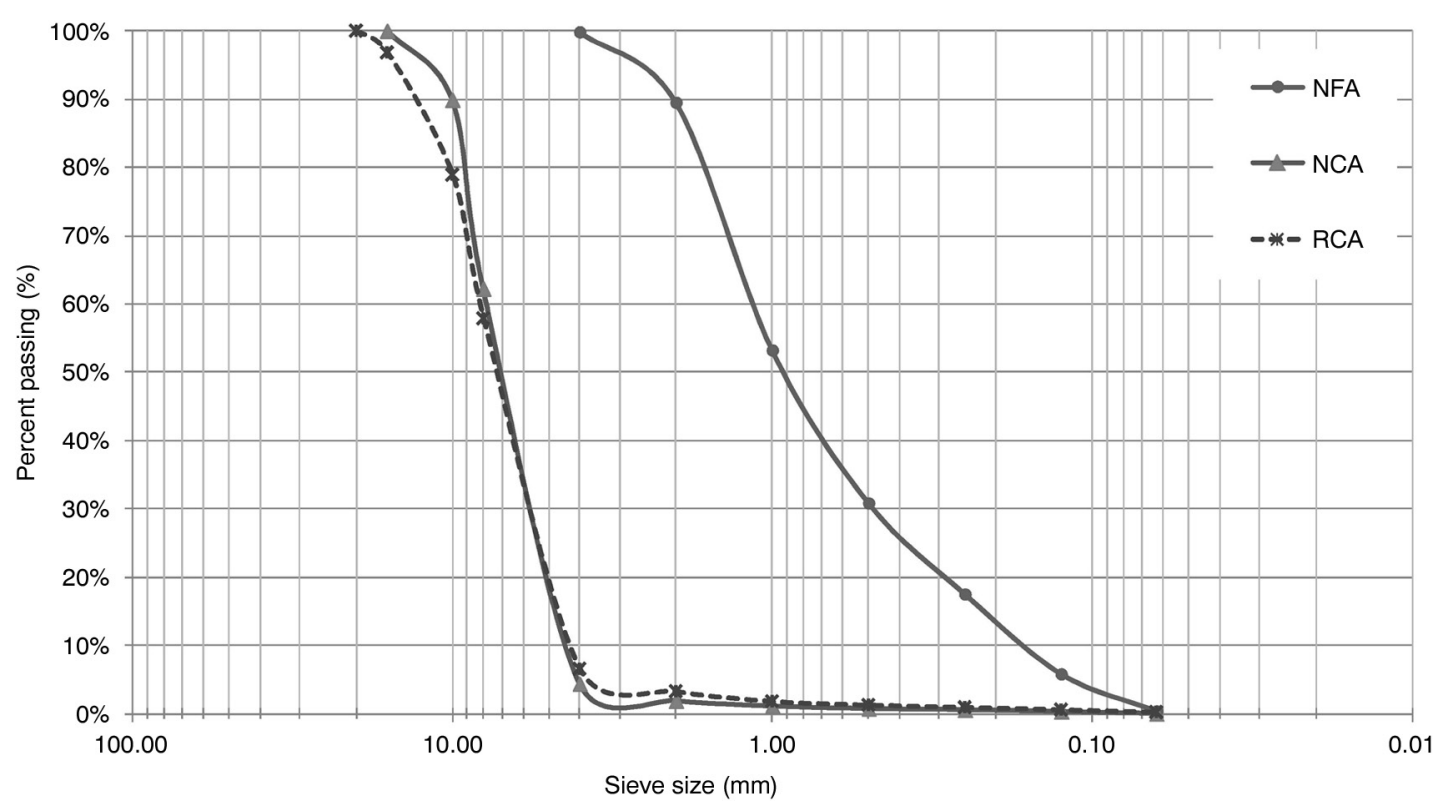

Figure 1. Aggregate grading curves.

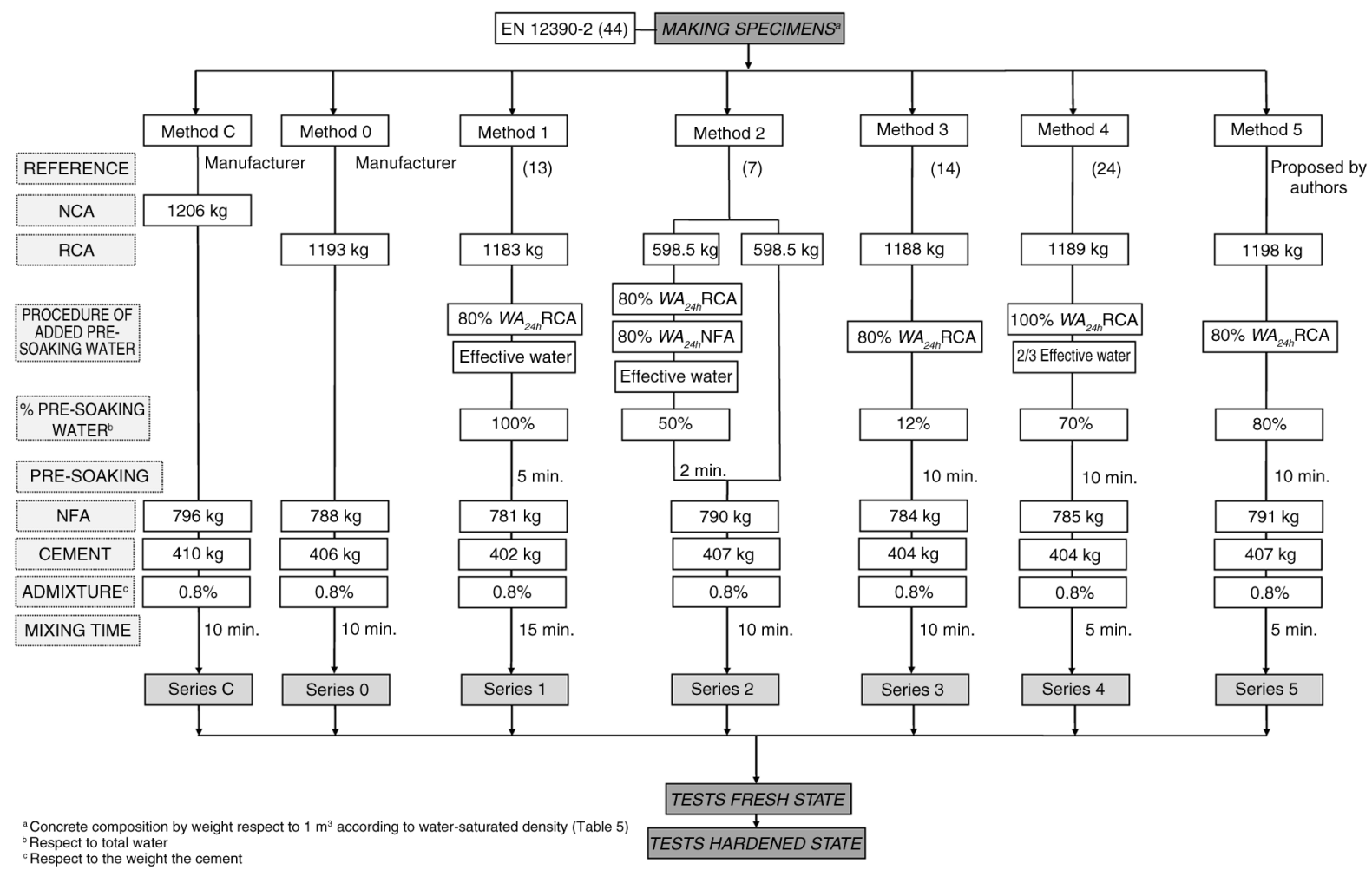

FIGURE 2. Making specimens process.

\subsubsection{Testing methods}

For the purpose of this study, the main properties of fresh and hardened concrete were tested according to the manufacturer's recommendations,
European standard EN 13198 (32) and EHE-08 restrictions (34). Table 4 shows the properties analysed and the guidelines and standards used.

In the case of fresh concrete, workability was measured in terms of slump using the Abrams cone 
TABLE 2. Concrete quality control according to manufacturer

\begin{tabular}{ll}
\hline Data & \\
\hline Cement type & BL I 42.5R \\
Superplasticizing admixture type & $\begin{array}{l}\text { Chryso }{ }^{\circledR} \text { fluid Optima 227 } \\
\text { Cylindrical } 15 \times 30 \mathrm{~cm}\end{array}$ \\
Sample type & \\
\hline Tests & 8 \\
\hline Consistency (Abrams cone in cm) & 42 \\
Compressive strength-7 days (Mpa) & 50 \\
Compressive strength-28 days (Mpa) &
\end{tabular}

method immediately after complete concrete mixing. Density testing was performed according to the reference standard (Table 4).

The properties of hardened concrete were measured in nine cubes measuring $150 \times 150 \times 150 \mathrm{~mm}$, cast using plastic moulds and compacted on a vibrating table, according to EN 12390-2:2009 (43). All cubes were removed from the moulds after $48 \mathrm{~h}$ and were cured in water at $22^{\circ} \mathrm{C}$ before testing. Compressive strength was determined by crushing at 7 and 28 days age. The results were referenced to $15 \times 30 \mathrm{~cm}$ cylindrical samples, using a conversion factor of 0.9 , as indicated in EHE-08 (34). Water-saturated density and water absorption tests were performed after samples were immersed in water for 3 days until constant mass was obtained, and then oven-dried for at least 3 days until constant mass was obtained according to the reference standards (Table 4).

\section{RESULTS AND DISCUSSION}

The pre-soaking methods were evaluated and compared with the control and non-pre-soaking methods (methods $\mathrm{C}$ and 0 , respectively). Table 5 summarizes the results of the tests performed on the different concrete series manufactured according to the methods discussed. Figures 3 to 9 summarize the values of the properties examined, showing the reference series (Series $\mathrm{C}$ and 0) and then the presoaked series (Series 1-5) arranged from the lowest

TABLE 3. Water content of mixtures

\begin{tabular}{lccccccc}
\hline Component & Series C & Series 0 & Series 1 & Series 2 & Series 3 & Series 4 & Series 5 \\
\hline Effective water (\%) & 8 & 8 & 8 & 8 & 8 & 8 & 8 \\
Added mixing water (\%) $^{\mathrm{b}}$ & 0 & 0 & 0.9 & 1.1 & 1.1 & 0.9 & 0 \\
Total water (\%) & 8 & 8 & 8.9 & 9.1 & 9.1 & 8.9 & 8 \\
Pre-soaking water (\%) & 0 & 0 & 8.9 & 4.6 & 1.1 & 6.2 & 6.4 \\
\hline
\end{tabular}

${ }^{\mathrm{a} B}$ By mass of cement plus aggregate (\%).

${ }^{\mathrm{b}}$ By mass of effective water (\%).

${ }^{c}$ Effective water plus added mixing water $(\%)$.

TABLE 4. Tests and procedures used to determine properties of concrete and restrictions

\begin{tabular}{|c|c|c|c|c|c|}
\hline \multirow[b]{2}{*}{ Tests } & \multirow[b]{2}{*}{ Procedure } & \multirow[b]{2}{*}{ Manufacturer $^{a}$} & \multirow[b]{2}{*}{$\begin{array}{l}\text { Classification } \\
\text { EHE-08 (34) }\end{array}$} & \multicolumn{2}{|c|}{ Limit EN 13198 (32) } \\
\hline & & & & $\begin{array}{c}\text { without } \\
\text { melting salts }\end{array}$ & $\begin{array}{c}\text { with melting } \\
\text { salts }\end{array}$ \\
\hline \multicolumn{6}{|l|}{ Fresh state Fresh state } \\
\hline \multirow[t]{5}{*}{ Consistency (Abrams cone in $\mathrm{cm}$ ) } & EN 12350-2:2009 (44) & soft (8) & dry $(0-2)$ & - & - \\
\hline & & & plastic (3-5) & & \\
\hline & & & soft (6-9) & & \\
\hline & & & fluid (10-15) & & \\
\hline & & & liquid (16-20) & & \\
\hline Fresh density $\left(\mathrm{kg} / \mathrm{m}^{3}\right)$ & EN 12350-6:2009 (45) & - & - & - & - \\
\hline \multicolumn{6}{|l|}{ Hardened state } \\
\hline Water-saturated density $\left(\mathrm{kg} / \mathrm{m}^{3}\right)$ & EN 12390-7:2009 (46) & - & - & - & - \\
\hline Water absorption (\%) & EN 13369:2004 Annex G (47) & - & - & $<7$ & $<6$ \\
\hline Compressive strength-7 days (Mpa) & EN 12390-3:2009 (48) & 42 & - & - & - \\
\hline Compressive strength-28 days (Mpa) & EN 12390-3:2009 (48) & 50 & - & 37 & 45 \\
\hline
\end{tabular}

${ }^{a}$ According to the manufacturer's concrete quality control data.

(-) No limitation for this parameter. 
TABLE 5. Tests, results of concrete series

\begin{tabular}{lccccccc}
\hline Test and result & Series C & Series 0 & Series 1 & Series 2 & Series 3 & Series 4 & Series 5 \\
\hline Fresh state & & & & & & & \\
\hline Consistency type (EHE-08) (34) & Soft & Plastic & Fluid & Liquid & Plastic & Soft & Dry \\
Abrams cone test (cm) (44) & 6 & 3 & 10 & 22 & 4 & 7 & 1 \\
Fresh density $\left(\mathrm{kg} / \mathrm{m}^{3}\right)(45)$ & 2387 & 2384 & 2360 & 2380 & 2366 & 2357 & 2368 \\
\hline Hardened state & & & & & & & 2378 \\
\hline Water-saturated density $\left(\mathrm{kg} / \mathrm{m}^{3}\right)(46)$ & 2412 & 2386 & 2380 & 2374 & 2376 & 2397 \\
Water absorption (\%) (47) & 5.05 & 1.97 & 2.17 & 2.40 & 2.10 & 2.30 & 1.80 \\
Compressive strength-7 days (Mpa) (48) & 50.36 & 44.64 & 47.62 & 43.11 & 39.80 & 44.99 & 53.13 \\
Compressive strength- 28 days (Mpa) (48) & 55.42 & 55.54 & 51.75 & 46.67 & 50.39 & 46.09 & 54.65 \\
\hline
\end{tabular}

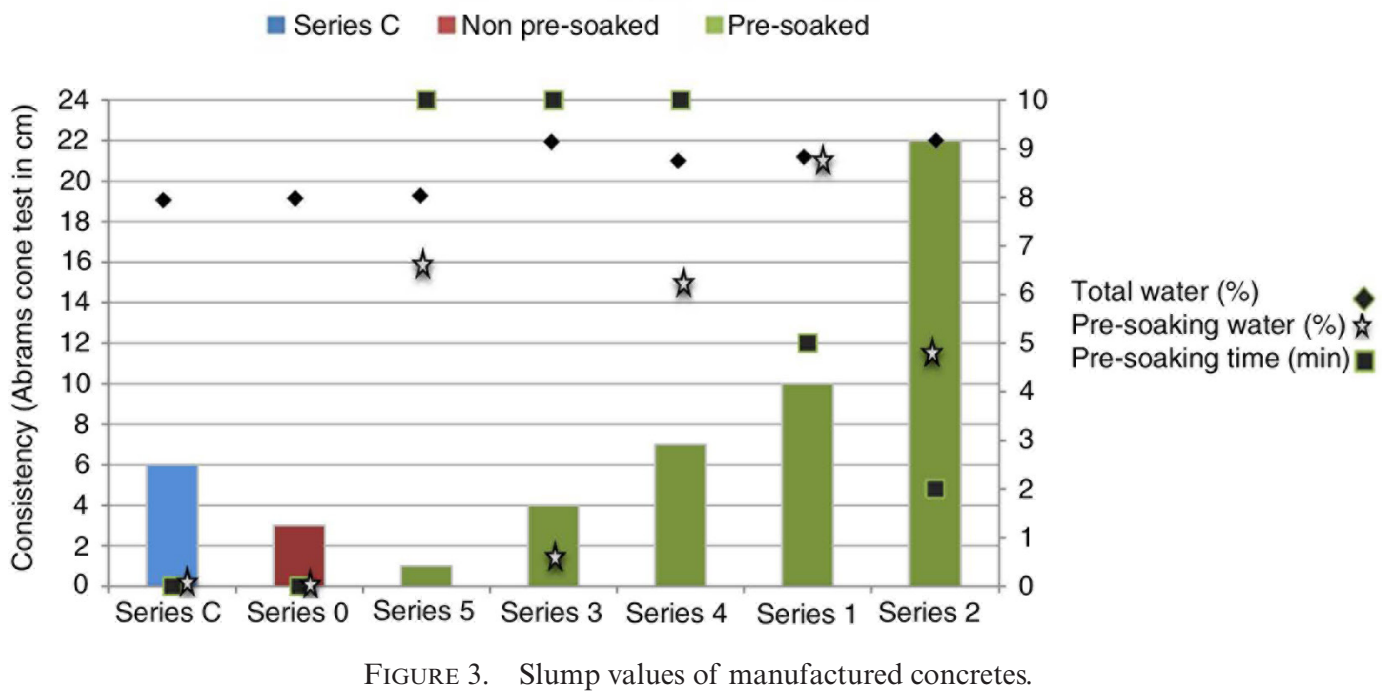

to the highest value obtained for each property. The results are discussed below.

\subsection{Fresh concrete}

\subsubsection{Consistency}

EN 13198 (32) does not restrict this parameter in pre-cast concrete. According to the literature consulted $(8,9)$, pre-cast products such as concrete blocks, paving flags or paving blocks are manufactured using a dry-mixed method. These simulates the actual industrial production process in which mixes are prepared with just enough water to produce a cohesive mix but with no slump/ workability. However, in the experimental study, according to the dosage and manufacturer's recommendations (Table 2), it is essential to maintain a workable mix. Therefore, the reference consistency used in this study was soft $(6-9 \mathrm{~cm})$ according to the recommendations of the manufacturer and EHE-08 (34).
Table 5 shows the consistency of the concrete series studied, together with the average Abrams cone test values. Results show values ranging from between 1 and $22 \mathrm{~cm}$ (dry and liquid consistency) depending on the amount of pre-soaking water, presoaking time and total water, including effective and added mixing water. As shown in Figure 3, Series 4 achieved the consistency and soft cone value closest to guidelines and recommendations, and corresponds to RC with a pre-soaking time of 10 minutes and $70 \%$ of total water (Figure 2).

Several authors have studied the importance of pre-soaking and mixing time, defining 10 minutes as the optimal pre-soaking time to obtain the best cone values $(7,23,24)$. This ensures optimum moisture percentage, giving the RCA a more effective surface (49). Figure 4 shows the relationship between slump values and pre-soaking time for the series tested. Since the high $\mathrm{R}$-square $\left(\mathrm{R}^{2}=0.858\right)$ value demonstrated a good fit between pre-soaking time and slump cone, a theoretical pre-soaking time of 10 minutes was predicted. This corresponded to Series 4, which had 


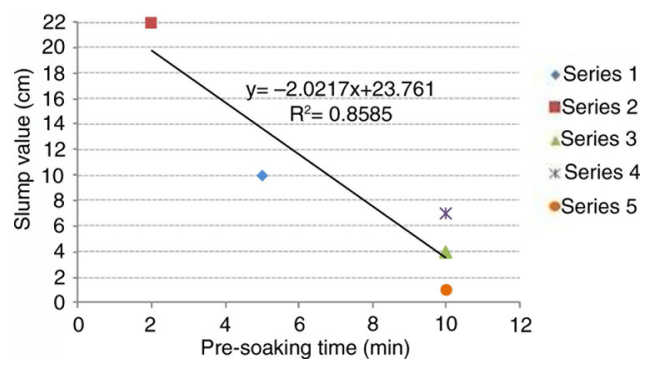

FIGURE 4. Relationship between pre-soaking time and slump cone values of pre-soaked series.

a cone value nearest to the reference value $(6 \mathrm{~cm})$. Shorter pre-soaking times ( 2 and 5 minutes) prevented the RCA from absorbing the water required to give a mixture with good workability (Series 2 and 1, respectively).

Figure 3 shows that the variable pre-soaking water did not affect the series tested. The same occurs with respect to total water content, since the percentage variation was small compared to other methods.

Based on the results obtained, therefore, presoaking affect the consistency of the concrete with respect to the pre-soaking time, but not with respect to the total water content. Therefore, to obtain the desired consistency for the manufacture of pre-cast concrete for street furniture, the RCA would need to be pre-soaked for 10 minutes to achieve a stable moisture level of around $90 \%$ of absorption, thereby preventing it from absorbing water from the other components, which would make the pre-soaking effective.

\subsubsection{Fresh density}

Neither EN 13198 (32) nor the manufacturer's recommendations include reference values for this parameter; however it has been included in this study because the density of the aggregate and the resulting concrete is an important factor in the manufacture of any type of concrete. The lower density of RA will contribute to concrete made with this aggregate being less workable, with a higher water demand in the state fresh (49-51). Table 5 and Figure 5 summarize the fresh density values of the concretes tested. Values ranged from $2357 \mathrm{~kg} / \mathrm{m}^{3}$ (Series 4) to $2380 \mathrm{~kg} / \mathrm{m}^{3}$ (Series 2), showing an insignificant reduction in density in all pre-soaked series, regardless of the amount of total and pre-soaking water or the pre-soaking time used, and with a maximum density reduction of only $1.3 \%$ (Series 4 ) with respect to the control series (Series C). The results are similar to those reported in other studies, such as that of Lopez-Gayarre et al. (52), who obtained variations of $5 \%$ or less. These reductions are explained not by the effect of pre-soaking but by the lower densities observed in the RCA compared to NCA (between 5\% and 15\% lower) (53).

\subsection{Hardened state concrete}

\subsubsection{Water-saturated density}

This parameter is included neither the manufacturer's recommendations nor in EN 13198 (32), although the analysis of the density in the cured state is justified since, as discussed above, the lower density of RA will lower the hardened-state resistance and durability of concrete made with this aggregate. However, this lower density may be of interest where a more lightweight concrete is needed. In addition, reducing the weight of pre-cast elements, and therefore improving handling, would lower industrial production costs.

The hardened-state density values of the series tested ranged from $2374 \mathrm{~kg} / \mathrm{m}^{3}$ (Series 2) to $2397 \mathrm{~kg} / \mathrm{m}^{3}$ (Series 5) (Table 5), a maximum decrease

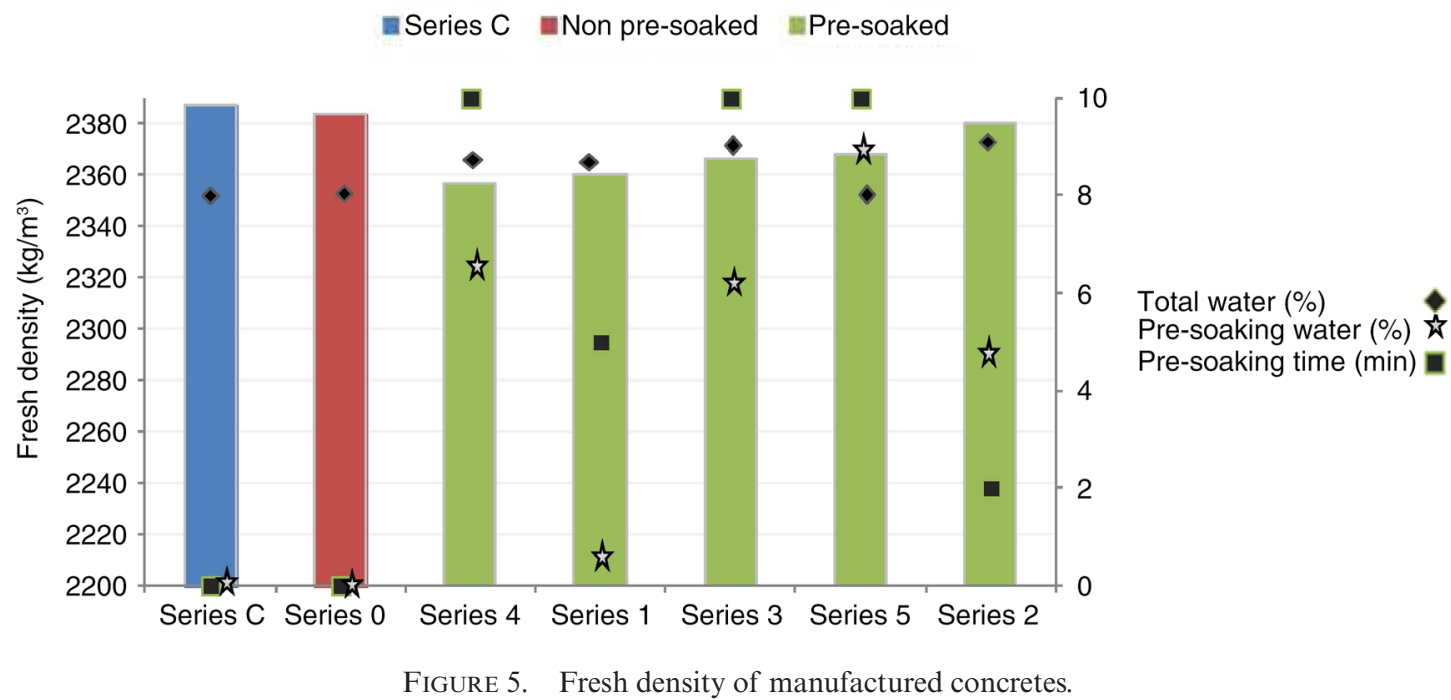

Materiales de Construcción 66 (321), January-March 2016, e076. ISSN-L: 0465-2746. doi: http://dx.doi.org/10.3989/mc.2016.01715 


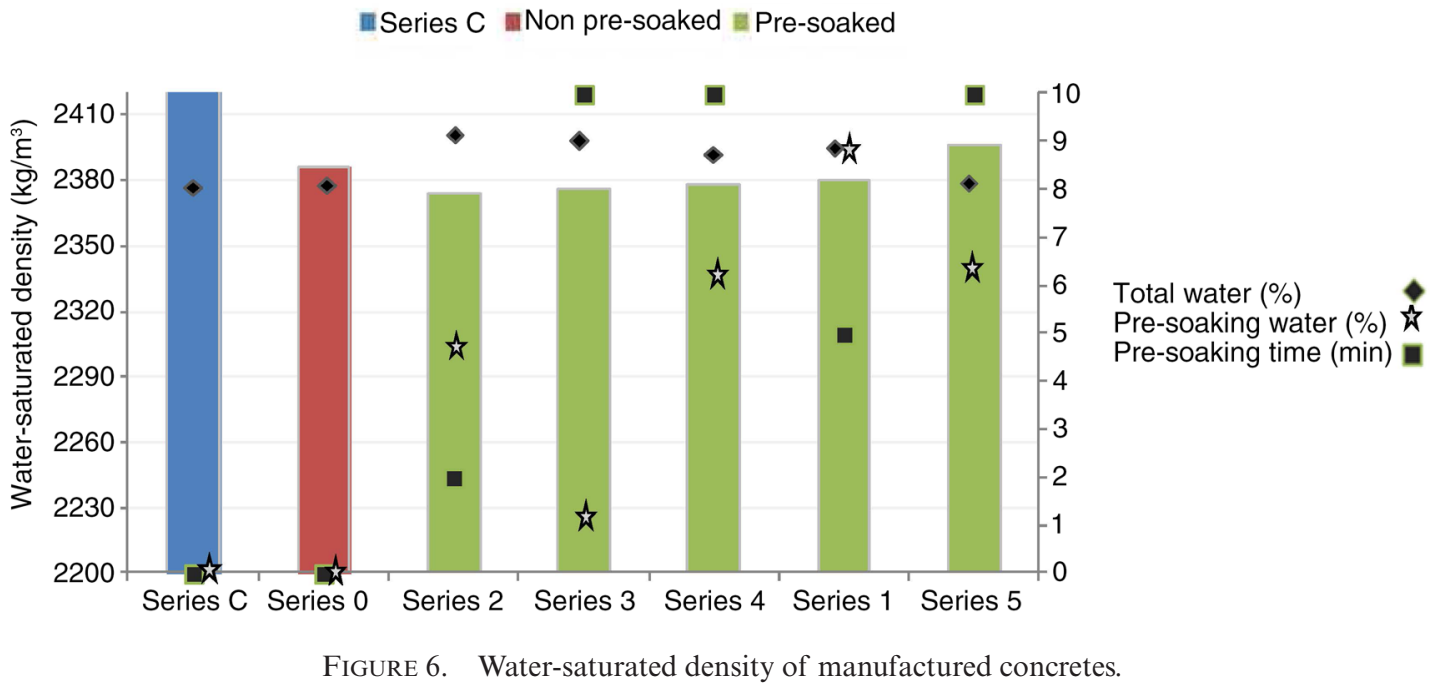

of $2.4 \%$ (Series 2) with respect to the reference value (Series C). Figure 6 shows how the variables analysed in each pre-soaking method (pre-soaking water and pre-soaking time) have no effect on the property analysed or the total water content (effective water plus added mixing water). This means that the slight decrease observed cannot be attributed to the presoaking method but to the mortar adhered to RA particles, since other studies have reported reductions of between $2 \%$ and $5 \%$, depending on the replacement percentage $(41,54)$.

\subsubsection{Water absorption}

EN 13198 recommends water absorption values with and without melting salts of less than $6 \%$ and $7 \%$, respectively. In fact, other studies consulted limited this parameter to similar values. Soutsos et al. (29), for example, recommend replacing $55 \%$ of coarse fraction in order to avoid exceeding the $6 \%$ limit.
The water absorption values of concrete made with RCA using different pre-soaking methods (Series 1-5) show that the values of all samples tested are within limits, and there are no significant differences between the different pre-soaking methods (Figures 2 and 7). However, differences are observed when the water absorption values of the series manufactured with NCA (Series C) and with RCA (Series 0-5) are compared, as discussed below (Table 5).

Contrary to what was expected, all RC absorption values observed in this study are below established limits, and are lower than that of the sample manufactured with NCA. The percentage reduction ranges from $52 \%$ to $64 \%$, corresponding to Series 2 and Series 5, respectively. So, natural concrete absorption is more than twice that of the RC absorption, which could be attributed to the lower content of pores interconnected in recycled concretes. Most studies report a greater absorption of water in the

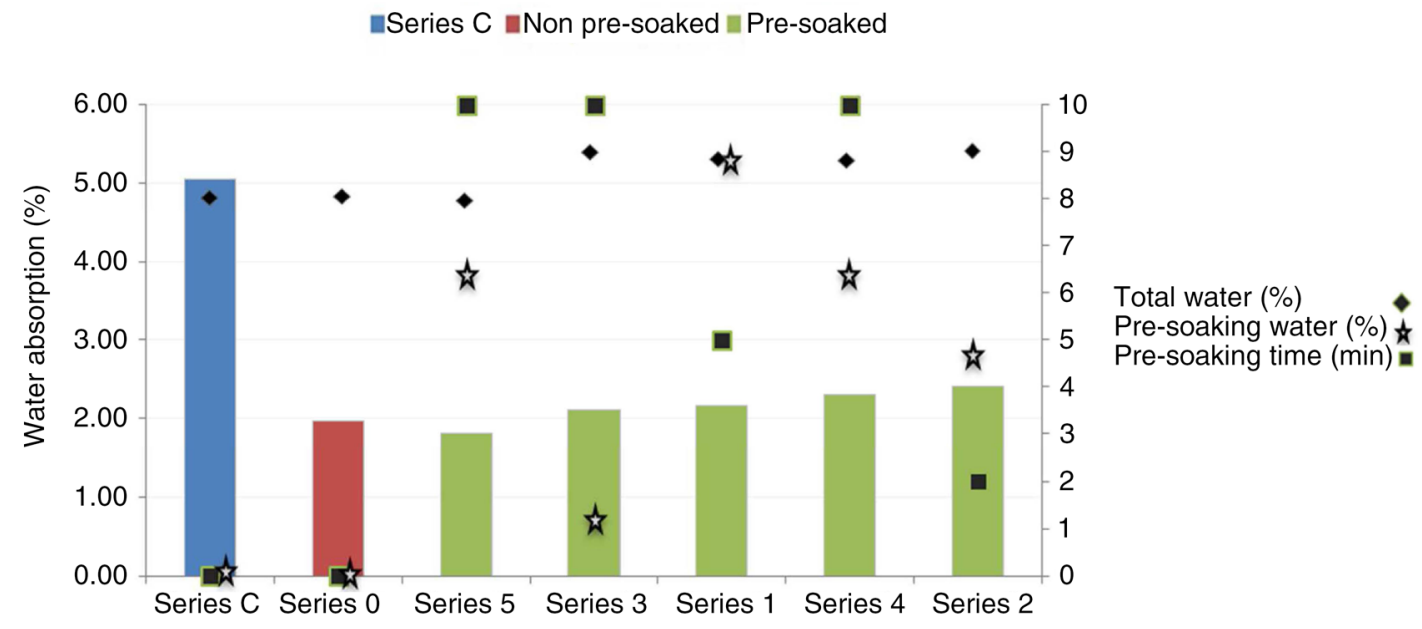

FIGURE 7. Water absorption of manufactured concretes. 
case of concrete made with RCA as a result of the incorporation of a more porous material such as cement paste adhering to the aggregate $(33,54,55)$. However, studies such as that of Gencel et al. (30) report reductions of $62 \%$, similar to those obtained in this study, with a similar coarse fraction replacement in the manufacture of concrete paving blocks.

This can be attributed to the discontinuous system of pores generated within the hardened concrete and better RCA bonding, which creates a continuous phase (aggregate particles enveloped by old cement paste). Therefore, the pores do not contribute to water absorption.

After analysing the results obtained from this study, it can be concluded that pre-soaking does not affect water absorption. However, the significant improvement in water absorption may be due more to the type of RCA used, mainly concrete, than the pre-soaking method.

\subsubsection{Compressive strength}

EN 13198 (32) recommends 28-day compressive strength values of between $30-37$ and $35-45 \mathrm{MPa}$ without and with melting salts, respectively; however, the manufacturer recommends over $50 \mathrm{MPa}$, due to the type and amount of cement used. The results (Table 5 and Figure 8) shows that all the samples tested are within limits (32) and meet the manufacturer's specifications (Table 2), except for 2 series (Series 2 and 4), which show a reduction of approximately $8 \%$.

An analysis of the benefits of pre-soaking (Figure 8) on resistance in the first period (7 days) of the pre-soaked series (Series 1-5) shows rapid growth in all series except Series 3, which has lower water content. Similar results were observed in the 7-day resistance of the non-pre-soaked series (Series 0), which leads us to conclude that increased resistance is due to pre-soaking, since this transfers water slowly to help in the curing process of the cement in the first days of age. According to Salem and Burdette (56) in Etxeberria et al. (14), the increased resistance of $\mathrm{RC}$ at an early age is due to the high absorption capacity and rough texture of the old mortar adhered to the RCA, which will give better bonding and interconnection between mortar and RCA. Soutsos et al. (57) obtained similar results in the manufacture of concrete building blocks, since pre-soaking ensures that there is sufficient water for mix hydration beyond 7 days.

At 28 days of age, the compressive strength of series manufactured with RCA (Series 0-5) does not follow the same trend observed in the preliminary curing ages (Figure 8). The findings for the presoaked series showed that compressive strength was not significantly affected by the pre-soaking method used. Therefore, it can be safely concluded that presoaking is only beneficial in the first days of age, provided the amount of pre-soaking water is controlled. This rapidly increases resistance (Figure 9) to above the EHE-08 (34) recommended value $(82 \%)$ for the strength class of the cement used in this study (42.5R).

The compressive strength at 7 days was not affected by the effect of total water content (Figure 8), although it slightly affected compressive strength at 28 days in series with a small inverse relationship between the total water content added to the mixture (effective water plus added mixing water) and compressive strength. Gonzalez-Fonteboa and Martinez-Abella (41) showed that lowering the total water content reduces the amount of free water in the mixture and increases resistance. However, an excessive decrease in free water can reduce RC resistance due to the poor hydration of cement particles, which affects the workability of the mix (58). These observations explain the result obtained from Series 5 (dry consistency and high resistance at 28 days).

घSeries C $₫$ Non pre-soaked $₫$ Pre-soaked

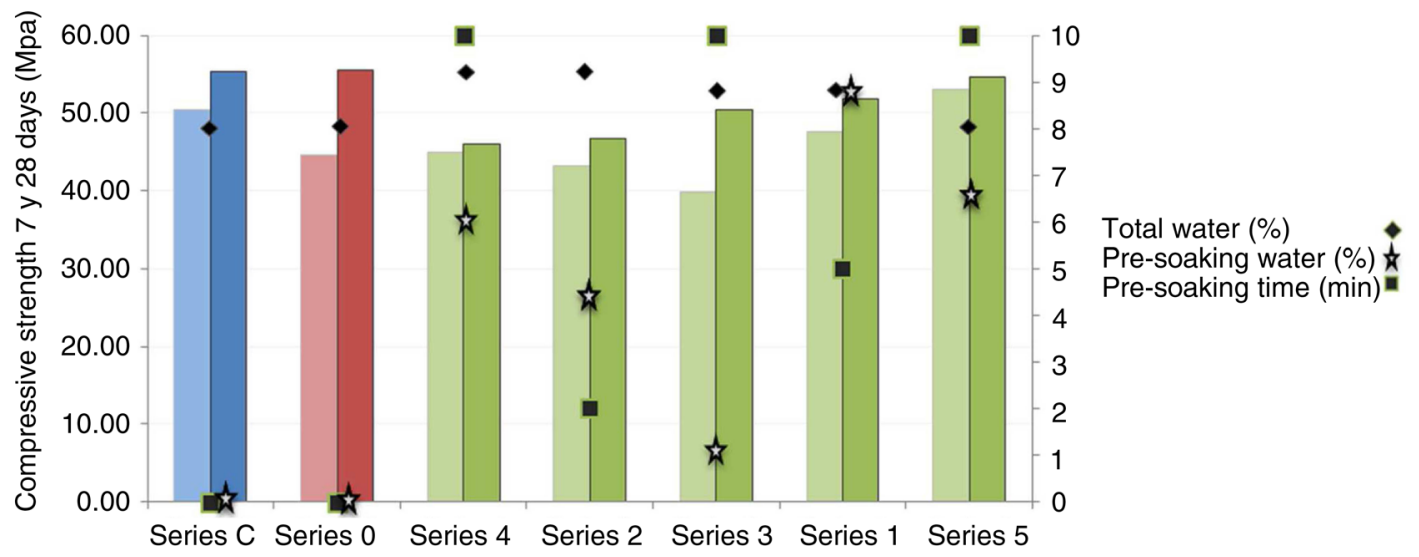

FIGURE 8. Compressive strength of manufactured concretes at 7 and 28 days. 


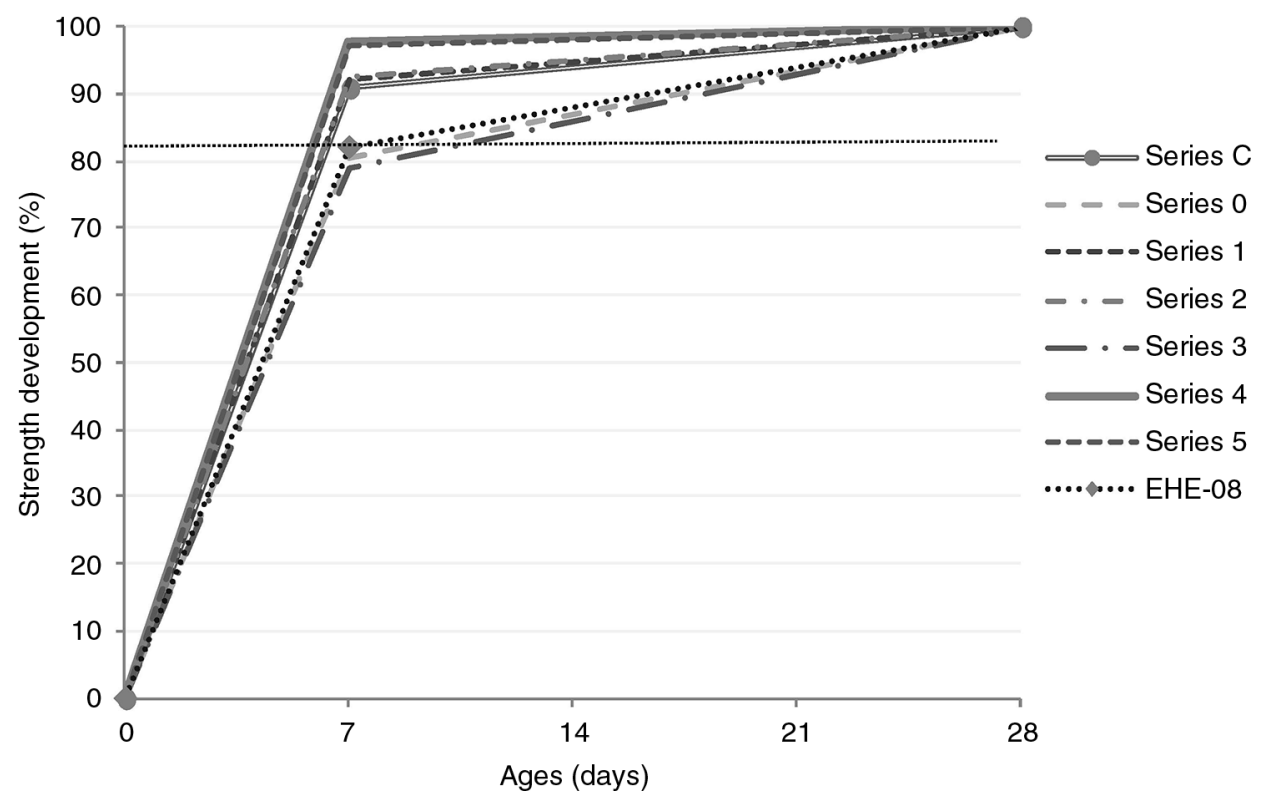

FIGURE 9. Strength of concretes from 7 to 28 days.

However, if the series manufactured with NCA (Series C) is compared to those manufactured with RCA (Series 0-5), replacing NCA with RCA reduces resistance provided the w/c ratio is maintained. The resistance results obtained in this study (Table 5 and Figure 8 ) show a reduction of between 1.4\% (Series 5) and $16.8 \%$ (Series 4) vs. series C, corresponding to a range of 46.09 MPa (Series 6) to 54.65 $\mathrm{MPa}$ (Series 5) at 28 days. A similar trend is seen at the age of 7 days, where in this case the minimum and maximum variation corresponds to Series $5(+5.5 \%)$ and Series 2 $(-14.4 \%)$. Similar results were obtained by other authors, who report reductions of between $12 \%$ (56) and $25 \%$ (14) in compressive strength at 28 days.

Several factors could explain the loss of strength $(59,60)$ : (i) the lower mechanical resistance of RA due to the presence of adhered mortar; (ii) the higher water absorption of RA (related to the previous factor); (iii) more weak areas in the RC.

Therefore, the results showed that pre-soaking adversely affected the mechanical strength of the concrete manufactured in this study, since without presoaking the RCA (Series 0 ) had a similar resistance to the series manufactured with NCA (Series C).

\section{CONCLUSIONS}

This study evaluates potential benefits of presoaking on the properties of pre-cast concrete for beach walkways made with RCA, following EN 13198 (32) and the manufacturer's recommendations. The advantages of pre-soaking were studied in terms of pre-soaking time and total water content. With regard to consistency, fresh density, water-saturated density, water absorption and compressive strength in the hardened state, it observed that pre-soaking RCA only affects consistency and compressive strength, and had little effect on other properties.

In general, the workability of concrete made with RCA improved with pre-soaking. This improvement was conditional on a 10 -minute pre-soaking time, but total water content has no effect.

The benefits of pre-soaking on the compressive strength of the samples tested showed that the initial resistance was enhanced due to the curing effect, which would be of special interest in the manufacture of precast concrete products. However, resistance at 28 days is lower than that of non-pre-soaked RCA, although certain methods guarantee that even such lower values are within the limits set by the manufacturer.

It can therefore be concluded that pre-soaked RCA does not enhance the physical-mechanical properties of pre-cast concrete, except in terms of workability. Due to the complexity and higher costs involved in the implementation of pre-soaking techniques on an industrial scale, the results suggest the use of non-pre-soaked recycled coarse aggregate as a replacement for NCA in the manufacture of precast concrete products for street furniture. Similar workability can be achieved by the addition of plasticizers, capable of providing the desired consistency to such concrete.

\section{ACKNOWLEDGEMENTS}

We would like to thank the staff of Prefabricados López y Mochón, S.L. in Atarfe in the Spanish province of Granada and Inertes Guhilar S.L. Alhendín in the Spanish province of Granada for their help in this study, and also the Departments 
of Building Construction and Civil Engineering of Granada University.

\section{REFERENCES}

1. Solís-Guzmán, J.; Marrero, M.; Montes-Delgado, M.V.; Ramirez-de-Arellano, A. (2009) A Spanish model for quantification and management of construction waste. Waste. Manage. 29 [9], 2542-548. http://dx.doi.org/10.1016/j.wasman. 2009.05.009.

2. Jiménez, C.; Barra, M.; Valls, S.; Aponte, D.; Vázquez, E. (2014) Durability of recycled aggregate concrete designed with the Equivalent Mortar Volume (EMV) method: Validation under the Spanish context and its adaptation to Bolomey methodology. Mater. Construcc. 64 [313], e006. http://dx.doi.org/10.3989/mc.2013.00913.

3. Vegas, I.; Ibañez, J.A.; Lisbona, A.; Sáez de Cortazar, A.; Frías, M. (2011) Pre-normative research on the use of mixed recycled aggregates in unbound road sections. Constr Build Mater. 25 [5], 2674-2682. http://dx.doi.org/10.1016/j. conbuildmat.2010.12.018.

4. Cuenca-Moyano, G.M.; Martín-Morales, M.; ValverdePalacios, I.; Valverde-Espinosa, I.; Zamorano, M. (2014) Influence of pre-soaked recycled fine aggregate on the properties of masonry mortar. Constr Build Mater. 70, 71-79. http://dx.doi.org/10.1016/j.conbuildmat.2014.07.098.

5. Saiz-Martínez, P.; González-Cortina, M.; FernándezMartínez, F. (2015) Characterization and influence of fine recycled aggregates on masonry mortars properties. Mater. Construcc. 65 [319], e058. http://dx.doi.org/10.3989/ mc. 2015.06014

6. Medina, C.; Juan, A.; Frías, M.; Sánchez de Rojas, M.I.; Moran, J. Ma.; Guerra. M.I. (2011) Characterization of concrete made with recycled aggregate from ceramic sanitary ware. Mater Construcc. 61 [304], 533-546. http://dx.doi. org/10.3989/mc.2011.59710.

7. Mas, B.; Cladera, A.; Del Olmo, T.; Pitarch, F. (2012) Influence of the amount of mixed recycled aggregates on the properties of concrete for non-structural use. Constr. Build. Mater. 27 [1], 612-622. http://dx.doi.org/10.1016/j. conbuildmat.2011.06.073.

8. Poon, C.S.; Kou, S.C.; Lam, L. (2002) Use of recycled aggregates in molded concrete bricks and blocks. Constr Build Mater. 16 [5], 281-289. http://dx.doi.org/10.1016/ S0950-0618(02)00019-3.

9. Jankovic, K.; Nikolic, D.; Bojovic, D. (2012) Concrete paving blocks and flags made with crushed brick as aggregate. Constr. Build. Mater. 28 [1], 659-663. http://dx.doi.org/ 10.1016/j.conbuildmat.2011.10.036

10. López Gayarre, L.; López-Colina, C.; Serrano, M.A.; LópezMartínez, A. (2013) Manufacture of concrete kerbs and floor blocks with recycled aggregate from C\&DW. Constr. Build. Mater. 40, 1193-1199. http://dx.doi.org/10.1016/j. conbuildmat.2011.11.040.

11. Xiao, Z.; Ling, T.Z.; Kou, S.C.; Wang, Q.; Poon, C.S. (2011) Use of wastes derived from earthquakes for the production of concrete masonry partition wall blocks. Waste Manage. 31 [8], 1859-1866. http://dx.doi.org/10.1016/j. wasman.2011.04.010

12. Poon, C.S.; Shui, Z.H.; Lam, L.; Fok, H.; Kou, S.C. (2004) Influence of moisture states of natural and recycled aggregates on the slump and compressive strength of concrete. Cement Concrete Res. 34 [1], 31-36. http://dx.doi.org/ 10.1016/S0008-8846(03)00186-8.

13. Cachim, P.B. (2009) Mechanical properties of brick aggregate concrete. Constr. Build. Mater. 23 [3], 1292-1297. http:// dx.doi.org/10.1016/j.conbuildmat.2008.07.023.

14. Etxeberria, M.; Vázquez, E.; Marí, A.; Barra, M. (2007) Influence of amount of recycled coarse aggregates and production process on properties of recycled aggregate concrete. Cement Concrete Res. 37 [5], 735-742. http://dx.doi.org/ 10.1016/j.cemconres.2007.02.002.

15. Rahal, K. (2007) Mechanical properties of concrete with recycled coarse aggregate. Build Environ. 42 [1], 407-415. http://dx.doi.org/10.1016/j.buildenv.2005.07.033.
16. De Juan, M.S.; Gutierrez, P.A. (2009) Study on the influence of attached mortar content on the properties of recycled concrete aggregate. Constr Build Mater. 23 [2], 872-877. http://dx.doi.org/10.1016/j.conbuildmat.2008.04.012.

17. Debieb, F.; Courard, L.; Kenai, S.; Degeimbre, R. (2009) Roller compacted concrete with contaminated recycled aggregates. Constr Build Mater. 23 [11], 3382-3387. http:// dx.doi.org/10.1016/j.conbuildmat.2009.06.031.

18. Ferreira, L.; de Brito, J.; Barra, M. (2011) Influence of the pre-saturation of recycled coarse concrete aggregates on concrete properties. Mag Concrete. Res. 63 [8], 617-627. http://dx.doi.org/10.1680/macr.2011.63.8.617.

19. González, J.G.; Robles, D.R.; Valdés, A.J.; Morán del Pozo, J.M.; Romero, M.I.G. (2013) Influence of Moisture States of Recycled Coarse Aggregates on the Slump Test. Adv Mat Res. 742, 379-383. http://dx.doi.org/10.4028/ www.scientific.net/AMR.742.379.

20. Mefteh, H.; Kebailli, O.; Oucief, H.; Berredjem, L.; Arabi, N. (2013) Influence of moisture conditioning of recycled aggregates on the properties of fresh and hardened concrete. J Clean Prod. 54, 282-288. http://dx.doi.org/10.1016/j. jclepro.2013.05.009.

21. Pelufo, M.J.; Domingo, A.; Ulloa, V.A.; Vergara, N.N. (2009) Analysis of moisture state of recycled coarse aggregate and its influence on compression strength of the concrete. Proceedings of the International Association for Shell and Spatial Structures (IASS) Symposium 2009, Valencia, Evolution and Trends in Design, Analysis and Construction of Shell and Spatial Structures, 28 September -2 October 2009, Universidad Politecnica de Valencia, Spain. http://hdl. handle.net/10251/6652.

22. Etxeberria, M.; Vázquez, E. (2010) Reacción álcali sílice en el hormigón debido al mortero adherido del árido reciclado, Alkali silica reaction in concrete induced by mortar adhered to recycled aggregate. Mater. Construcc. 60 [297], 47-58. http://dx.doi.org/10.3989/mc.2010.46508.

23. Cabral, A.E.B.; Schalch, V.; Dal Molin, D.C.C.; Ribeiro, J.L.D. (2010) Mechanical properties modeling of recycled aggregate concrete. Constr Build Mater. 24 [4], 421-430. http://dx.doi.org/10.1016/j.conbuildmat.2009.10.011.

24. Evangelista, L.; De Brito, J. (2007) Mechanical behaviour of concrete made with fine recycled concrete aggregates. Cement. Concrete. Comp. 29 [5], 397-401. http://dx.doi.org/ 10.1016/j.cemconcomp.2006.12.004

25. Kou, S. (2006) Reusing recycled aggregates in structural concrete. PhD Thesis, Politechnic University, The Hong Kong. 278.

26. Kou, S.C.; Poon, C.S.; Wan, H.W. (2012) Properties of concrete prepared with low-grade recycled aggregates. Constr Build Mater. 36, 881-889. http://dx.doi.org/10.1016/j. conbuildmat.2012.06.060.

27. Poon, C.S.; Kou, S.C.; Wana, H.W.; Etxeberria, M. (2009) Properties of concrete blocks prepared with low grade recycled aggregates. Waste Manage. 29 [9], 2369-2377. http:// dx.doi.org/10.1016/j.wasman.2009.02.018.

28. Poon, C.S.; Chan, D. (2006) Paving blocks made with recycled concrete aggregate and crushed clay brick. Constr. Build. Mater. 20 [8], 569-577. http://dx.doi.org/10.1016/j. conbuildmat.2005.01.044.

29. Soutsos, M.N.; Tang, K.; Millard, S.G. (2011) Use of recycled demolition aggregate in pre-cast products, phase II: Concrete paving blocks. Constr. Build. Mater. 25 [7], 3131-3143. http:// dx.doi.org/10.1016/j.conbuildmat.2010.12.024.

30. Gencel, O.; Ozel, C.; Koksal, F.; Erdogmus, E.; MartínezBarrera, G.; Brostow, W. (2012) Properties of concrete paving blocks made with waste marble. J Clean Prod. 21 [1], 62-70. http://dx.doi.org/10.1016/j.jclepro.2011.08.023.

31. Soutsos, M.N.; Tang, K.; Millard, S.G. (2012) The use of recycled demolition aggregate in pre-cast concrete products - Phase III: Concrete pavement flags. Constr. Build. Mater. 36, 674-680. http://dx.doi.org/10.1016/j.conbuildmat.2012. 06.045 .

32. European standard EN 13198 (2004) Pre-cast concrete products. Street furniture and garden products. CEN.

33. Zega, C.J.; Di Maio, A.A. (2011) Use of recycled fine aggregate in concretes with durable requirements. Waste Manage. 
31 [11], 2336-2340. http://dx.doi.org/10.1016/j.wasman. 2011.06.011.

34. EHE-08. (2008) Ministerio de la Presidencia. Real Decreto 1247/2008, de 18 de julio, por el que se aprueba la Instrucción de hormigón estructural, Boletín Oficial del Estado, BOE 2008; 203 (suplemento):1-203.

35. European standard EN 933-1. (2012) Tests for geometrical properties of aggregates. Part 1: Determination of particle size distribution. Sieving method. CEN.

36. European standard EN 933-2. (1996) Tests for geometrical properties of aggregates. Part 2: Determination of particle size distribution. Test sieves, nominal size of apertures. CEN.

37. European standard EN 1097-6. (2000) Tests for mechanical and physical properties of aggregates. Part 6: Determination of particle density and water absorption. CEN

38. European standard EN 1097-5. (2009) Tests for mechanical and physical properties of aggregates. Part 5: Determination of the water content by drying in a ventilated oven. CEN.

39. European standard EN 933-11. (2009) Tests for geometrical properties of aggregates, Part 11: Classification test for the constituents of coarse recycled aggregate. CEN.

40. Agrela, F.; De Juan, M.S.; Ayuso, J.; Geraldes, V.L.; Jiménez, J.R. (2011) Limiting properties in the characterisation of mixed recycled aggregates for use in the manufacture of concrete. Constr. Build. Mater. 25 [10], 3950-3955. http://dx.doi. org/10.1016/j.conbuildmat.2011.04.027.

41. González-Fonteboa, B.; Martínez-Abella, F. (2008) Concretes with aggregates from demolition waste and silica fume. Materials and mechanical properties. Build. Environ. 43 [4], 429-437. http://dx.doi.org/10.1016/j.buildenv.2007. 01.008 .

42. Martín-Morales, M.; Sánchez-Roldán, Z.; Zamorano, M.; Valverde-Palacios, I. (2013) Métodos granulométricos en la caracterización del árido reciclado para su uso en hormigón estructural. Size grading methods to characterize construction and demolition waste for its use in structural concrete. Mater. Construcc. 63 [310], 235-249. http:// dx.doi.org/10.3989/mc.2013.mc.06511.

43. European standard EN 12390-2. (2009) Testing fresh concrete. Part 2: Making and curing specimens for strength tests. CEN.

44. European standard EN 12350-2. (2009) Testing fresh concrete. Part 2: Slump-test. CEN.

45. European standard EN 12350-6. (2009) Testing fresh concrete. Part 6: Density. CEN.

46. European standard EN 12390-7. (2009) Testing hardened concrete. Part 7: Density of hardened concrete. CEN.

47. European standard EN 13369. (2006) Common rules for pre-cast concrete products. CEN.

48. European standard EN 12390-3. (2009) Testing hardened concrete. Part 3: Compressive strength of test specimens. CEN.
49. Ismail, S.; Ramli, M. (2014) Effect of Different Moisture States of Surface-Treated Recycled Concrete Aggregate on Properties of Fresh and Hardened Concrete, World Academy of Science, Engineering and Technology International Journal of Civil. Architectural Science and Engineering. 8: 65-71. International Science Index 85; 2014.

50. Rodrigues, F.; Evangelista, L.; de Brito, J. (2013) A New Method to Determine the Density and Water Absorption of Fine Recycled Aggregates. Materials. Researc. 16 [5], 1045-1051. http://dx.doi.org/10.1590/S1516-14392013005000074.

51. Canovas, M.F. (2004) Hormigón, Séptima edición, España: Madrid. ISBN: 84-7493-125-8.

52. López-Gayarre, F.; Serna, P.; Domingo-Cabo, A.; SerranoLópez, A.; López-Colina, C. (2009) Influence of recycled aggregate quality and proportioning criteria on recycled concrete properties. Waste. Manage. 29 [12], 3022-3028. http://dx.doi.org/10.1016/j.wasman.2009.07.010.

53. Bustillo Revuelta, M. (2008) Hormigones y Morteros, Fueyo Editores, España: Madrid. ISBN: 978-84-935279-1-4.

54. Pérez-Benedicto, J.A.; del Río-Merino, M.; Peralta-Canudo, J.L.; de la Rosa-La Mata, M. (2012) Mechanical characteristics of concrete with recycled aggregates coming from prefabricated discarded units. Mater. Construcc. 62 [305] 25-37. http://dx.doi.org/10.3989/mc.2011.62110.

55. Duan, Z.H.; Poon, C.H. (2014) Properties of recycled aggregate concrete made with recycled aggregates with different amounts of old adhered mortars. Mater. Des. 58, 19-29. http://dx.doi.org/10.1016/j.matdes.2014.01.044.

56. Salem, R.M.; Burdette, E.G. (1998) Role of chemical and mineral admixture on physical properties and frost-resistance of recycled aggregate concrete. ACI Mater. J. 95 [5], 558-563. http://dx.doi.org/10.14359/398.

57. Soutsos, M.N. Tang, K.: Millard, S.G.; (2011) Concrete building blocks made with recycled demolition aggregate. Constr. Build. Mater. 25 [2], 726-735. http://dx.doi.org/ 10.1016/j.conbuildmat.2010.07.014.

58. De Brito, J.; Saikia, N. (2013) Chapter 5: Use of Construction and Demolition Waste as Aggregate: Properties of Concrete. In: De Brito J, Saikia N. Recycled Aggregate in Concrete, Green Energy and Technology, Springer-Verlag London. 54: 229-337. http://dx.doi.org/10.1007/978-1-4471-4540-0_5.

59. Sánchez de Juan, M. (2005) Estudio sobre la utilización de árido reciclado para la fabricación de hormigón estructural (Study on the use of recycled aggregate in structural concrete). Tesis Doctoral. Universidad Politécnica de Madrid. ETSI de Caminos, Canales y Puertos, España: Madrid. 502.

60. López Gayarre, F. (2008) Influencia de la variación de los parámetros de dosificación y fabricación de hormigón reciclado estructural sobre sus propiedades físicas y mecánicas, Tesis Doctoral, Universidad de Oviedo, España: Gijón. 310. 